\title{
Stable carbon isotope changes during artificial charring of propagules
}

\author{
I. Poole ${ }^{\mathrm{a}, *}$, F. Braadbaart ${ }^{\mathrm{a}}$, J.J. Boon ${ }^{\mathrm{b}}$, P.F. van Bergen ${ }^{\mathrm{a}}$ \\ ${ }^{\mathrm{a}}$ Geochemistry, Earth Sciences, Utrecht University, PO Box 80021, 3508 TA Utrecht, The Netherlands \\ ${ }^{\mathrm{b}}$ AMOLF, FOM Institute, Kruislaan 407, 1098 SJ, Amsterdam, The Netherlands
}

\begin{abstract}
Charred organic remains are ubiquitous in the archaeological and fossil record and are often used to interpret past environments and climate. This study focuses on the physical and chemical alteration that takes place during heating (i.e. charring). Modifications to the internal and external morphology were noted alongside the change in molecular and stable carbon isotope signature. Molecular analyses were undertaken using direct temperature resolved mass spectrometry and the stable carbon isotopes determined using isotope ratio mass spectrometry. The results of this study document a general enrichment in ${ }^{13} \mathrm{C} /{ }^{12} \mathrm{C}$ composition of charred material which could reflect the changes observed in both the molecular composition and the relative proportions of the molecules formed. These results indicate that spurious results might be inferred when comparing the stable carbon isotope signature of charred/charcoalified material with uncharred organic matter
\end{abstract}

(C) 2002 Elsevier Science Ltd. All rights reserved.

\section{Introduction}

Stable carbon isotope data of bulk organic matter $(\mathrm{OM})$ are often used to infer changes in palaeoenvironment and palaeoclimate (e.g. Beerling and Jolley, 1998; Gröcke et al., 1999; Hesselbo et al., 2000). However, it is now widely known that bulk OM is a weighted mean average of different types of organic matter, each having its own isotope composition. One possible way to reduce this complexity is to use morphologically welldefined organic (land) plant remains, i.e. fossils of leaves (whole leaves and cuticles), wood, propagules etc. (Gröcke, 1998; Lücke et al., 1999; Arens et al., 2000; Hesselbo et al., 2000; van Bergen and Poole, 2001; Peters-Kottig et al., 2001). An additional advantage of plant fossils is the fact that specific anatomical and morphological characters of these remains can also be used as they may reflect certain environmental conditions

* Corresponding author. Tel.: + 31-30-2535068; fax: + 3130-2535030.

E-mail address: i.poole@geo.uu.nl (I. Poole).
(Kürschner et al., 1996; Wheeler and Baas, 1993; Wiemann et al., 1998, 1999).

The fossil plant material regularly used in stable carbon isotope studies includes thermally altered samples such as coal and charcoal. Although 'charcoal' is a term usually used when referring to wood, any organ that has been heated in an oxygen-depleted atmosphere can be considered to be charcoalified, or if combustion is incomplete, 'charred'. A charred zone of chemically and physically heat-altered tissue usually occurs between the outer portion of the organ which has undergone complete combustion (charcoalified zone) and the inner unchanged portion (Jones et al., 1993). During the phases before complete charcoalification, physical and chemical changes occur. The organ is more susceptible to break-up, they become physically smaller, reflectance changes as does isotopic composition (Jones et al., 1993). Charcoal is formed commonly under natural conditions during wildfires and can be abundant in the fossil record (e.g. Jones and Chaloner, 1991; Jones et al., 1993), archaeological horizons (e.g. Figueiral and Willcox, 1999) and recent soils and sediments (e.g. Schmidt et al., 1999; Schmidt and Noack, 2000). From a detailed survey of 
the literature, the definition of the term char is unclear (e.g. Sricharoenchaikul et al., 2001). Therefore, for the purpose of this work, char is defined as the black residue obtained after heating organic matter in an oxygendepleted atmosphere regardless of temperature and time (since char can be produced after a few minutes at relatively high, i.e. $>400{ }^{\circ} \mathrm{C}$, or for several hours at relatively low, i.e. $<190{ }^{\circ} \mathrm{C}$, temperatures).

Within the archaeological and fossil record, wood, fruits and seeds are the most commonly encountered plant macrofossils (Reid and Chandler, 1933; Collinson, 1983; Poole, 2000) and therefore charcoalified remains of these organs provide important information regarding past environments, including climate, and civilisations (Marino and DeNiro, 1987). However, although charcoal has been widely studied, to date little consideration has been paid to the extent to which charred or charcoalified organic material has been changed in relation to both its stable carbon isotope- and molecular composition. One study that has tried to address the problem of using carbon isotopes from archaeological charcoalified plant material is that of DeNiro and Hastorf (1985) who focused on a selection of both modern and archaeological plant remains. They found that modern plant parts expressed an isotopic variation up to $2 \%$ whereas uncarbonized prehistoric plants had carbon isotopic values that differ by as much as $8 \%$. Archaeological plants carbonized prior to deposition are similar (differences up to $3 \%$ ) to the isotopic values of their modern counterparts. In the case of pods of Pisum sativum L. (pea), DeNiro and Hastorf (1985) note that the carbonized organic matter also became more ${ }^{13} \mathrm{C}$ depleted when compared with material that had not been carbonized. Therefore there is a fundamental need to understand both the distribution of isotopes within parts of the same plant and the changes that occur when plant matter undergoes fossilization (DeNiro and Hastorf, 1985), including charcoalification. It is essential that an assessment is made of the inherent changes in $\delta^{13} \mathrm{C}$ that take place during the process of charcoalification in combination with molecular alterations such that the $\delta^{13} \mathrm{C}$ values of fossil material can be interpreted with more accuracy. This is the focus of the work presented here.

The objective of this study was therefore to assess the stable carbon isotope changes that occurred during thermal treatment, under oxygen-depleted conditions at atmospheric pressure, of morphologically well-defined plant organs, i.e. propagules. The use of propagules has two main advantages, viz. (1) they are morphologically well defined and samples from different batches can thus be compared, and (2) the natural variation in chemical composition can be minimized. Peas are propagules composed of a seed coat enveloping two cotyledons which constitute the major portion of the seed. The cotyledons are composed primarily of polysaccharides (i.e. starch; $\approx 45 \%$ ), a smaller proportion of proteins $(<25 \%)$ and a minute amount of fat $(<3 \%$; Daveby et al., 1993). Only the cotyledons were subject to elemental analyses and direct temperature resolved mass spectrometry (DTMS) to determine chemical changes, and isotope ratio mass spectrometry (IRMS) to monitor changes in isotope composition.

\section{Material and methods}

\subsection{Samples}

Peas (Pisum sativum) were collected from the Centre for Genetic Resources, the Netherlands (CGN). Two varieties were selected: 'Graauwe Erwt' (GE; CGN 10198) and 'Noord-Hollandse Rozijnerwt' (NHR; CGN 10293). Both are Dutch varieties and are qualified as landraces. The two varieties were sown and harvested in the Hortus Botanicus of the University of Leiden in the summer of 1999.

\subsection{Charring}

Ten intact pea seeds were heated in a pre-heated tube furnace at temperatures ranging from 130 to $700{ }^{\circ} \mathrm{C}$

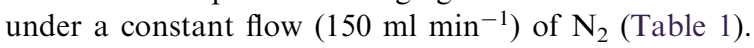
Gases and volatiles were vented. All samples were heated for 1 hour and then left to cool under a stream of nitrogen to prevent any oxidation. In addition, at three temperatures $\left(190,250\right.$ and $340{ }^{\circ} \mathrm{C}$ ) samples were also heated for $2 \mathrm{~h}$ to gauge the effect of heating at prolonged

Table 1

The percentage $\mathrm{C}$ and $\mathrm{H}$ and weight loss with heating for $1 \mathrm{~h}$ based on an average of 10 peas (Pisum sativum variety 'Graauwe erwt')

\begin{tabular}{llll}
\hline $\begin{array}{l}\text { Temperature } \\
\left({ }^{\circ} \mathrm{C}\right)\end{array}$ & $\begin{array}{l}\text { Carbon } \\
(\%)\end{array}$ & $\begin{array}{l}\text { Hydrogen } \\
(\%)\end{array}$ & $\begin{array}{l}\text { Weight loss } \\
(\%)\end{array}$ \\
\hline Untreated & 42.50 & 6.32 & 0.00 \\
130 & 42.60 & 6.15 & 10.3 \\
160 & 43.50 & 6.23 & 13.9 \\
190 & 45.50 & 6.04 & 18.2 \\
220 & 50.00 & 6.14 & 23.5 \\
235 & - & - & 29.2 \\
250 & 59.00 & 5.27 & 42.0 \\
270 & 64.21 & 5.34 & 49.1 \\
290 & 67.00 & 5.04 & 54.3 \\
310 & 74.50 & 5.14 & 59.2 \\
340 & 76.00 & 4.79 & 62.7 \\
370 & 77.50 & 4.42 & 67.3 \\
400 & 78.50 & 4.09 & 68.9 \\
440 & 79.25 & 3.54 & 73.2 \\
500 & 79.75 & 3.01 & 75.2 \\
600 & 80.25 & 2.08 & 77.7 \\
700 & 80.50 & 1.53 & 79.1 \\
\hline
\end{tabular}


temperature on the stable carbon isotope signature. After the heating experiments, weight loss was determined. Prior to chemical analyses the seed coat was separated from the cotyledons. Only the latter was used for elemental analyses, DTMS and IRMS.

\subsection{Microscopy}

Morphological changes in complete peas were monitored by observing visual changes in external gross morphology. The internal morphology was examined on polished resin-embedded entire specimens using a Zeiss Axioskop reflected light microscope.

\subsection{Elemental analyses}

CHN analyses were performed using a LECO CHN1000 analyser. The furnace temperature was set at $1050{ }^{\circ} \mathrm{C}$. Values stated in Table 1 are based on two measurements corrected for $\mathrm{H}_{2} \mathrm{O}$ but not corrected for their ash contents (ash content is $<1 \%$ ).

\subsection{Direct temperature resolved mass spectrometry (DTMS)}

In-source mass spectrometric experiments were performed on a JEOL SX-102 double focusing mass spectrometer using a direct insertion probe equipped with a resistively heated $\mathrm{Pt}-\mathrm{Rh}$ (9:1) filament. The probe filament was temperature programmed to heat at a rate of $0.5 \mathrm{~A} \mathrm{~min}^{-1}$ to $800{ }^{\circ} \mathrm{C}$. Ions were generated by $16 \mathrm{eV}$ EI ionization and extracted at $10 \mathrm{kV}$. The mass spectrometer was scanned from $m / z$ 20-1000 with a cycle time

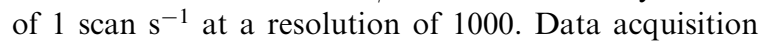
and processing were performed on-line.

\subsection{Stable carbon isotope ratio mass spectrometry (IRMS)}

On-line bulk stable carbon isotope analyses were performed using a Fisons Instruments NA 1500 Elemental Analyser (EA) coupled via a ConFlo II interface to a Finningan MAT Delta Plus isotope ratio mass spectrometer (IRMS). Briefly, approximately $1 \mathrm{mg}$ of sample was weighed into a tin container, sealed and subsequently placed into an AS 200 autosampler connected to the EA. Sealed samples were dropped into a combustion oven held at $1000-1500{ }^{\circ} \mathrm{C}$. Gases produced were flushed through an oxidation reactor $\left(1020^{\circ} \mathrm{C}\right)$ and subsequently over a reduction reactor $\left(650^{\circ} \mathrm{C}\right)$. Water was removed using a water trap and the remaining gas mixture was separated using a chromatographic column. The gases including $\mathrm{CO}_{2}$ were then transferred to the IRMS via the ConFlo II Interface; $\delta^{13} \mathrm{C}$ values of the $\mathrm{CO}_{2}$ were calibrated against reference $\mathrm{CO}_{2}$ (5.0 Airproducts) of known isotope composition which was introduced directly into the source at the end of each run. All values are based on replicate samples with accuracy better than $0.1 \%$. The precision of these values, against a laboratory standard that was run before and after each set of samples, was within $0.1 \%$.

\section{Results and discussion}

\subsection{Morphology}

The gross morphology of the peas did not change markedly during the heating process apart from some cracking to the external surface, a small reduction in size at higher temperatures and an increased darkening with temperatures up to $200{ }^{\circ} \mathrm{C}$ (from light brown to black). Above this temperature all specimens were black. This is contrary to the findings of Jones et al. (1993) who documented a significant decrease in the size of the organ undergoing charcoalification. Interestingly, the seed coat appeared to adhere to the underlying cotyledons up to c. $290{ }^{\circ} \mathrm{C}$ and at temperatures above $340{ }^{\circ} \mathrm{C}$. Between 290 and $340{ }^{\circ} \mathrm{C}$ the seed coat became disassociated from the cotyledons.

In contrast the internal structure underwent drastic alteration. Starch grains filled the greater proportion of the distinct cells in both the untreated peas and those heated to $190{ }^{\circ} \mathrm{C}$. At higher temperatures both the cell walls and starch grains became increasingly indistinct until $270{ }^{\circ} \mathrm{C}$, whereupon the cell morphology disappeared. Associated with this was the formation of holes between the cells at temperatures above $190{ }^{\circ} \mathrm{C}$. These increased in size until they contributed the greatest proportion within the cotyledons. This is similar to the voids seen in naturally formed charred coal particles (Bailey et al., 1990). These observations indicate that reactions occur during the charring/charcoalification process both in and between the cells but leave the gross morphology intact. Interestingly, the fact that starch grains remain present as visual distinct entities within all heated specimens, although chemically completely changed (see below), clearly indicates that reactions occurring must involve molecules immediately adjacent to one another, reducing the probability of completely random chemical reactions. Thus the visually distinct areas within the charred specimens are most likely also chemically distinct.

\subsection{Elemental analyses}

The elemental analyses revealed an expected increase in the relative percentage of carbon and decrease in the relative percentage of hydrogen, with the major change occurring between 200 and $350{ }^{\circ} \mathrm{C}$ (Table 1). Carbon increased from c. $40 \%$ to c. $80 \%$, with a corresponding decrease in hydrogen from c. $6 \%$ to c. $1 \%$. These relative 


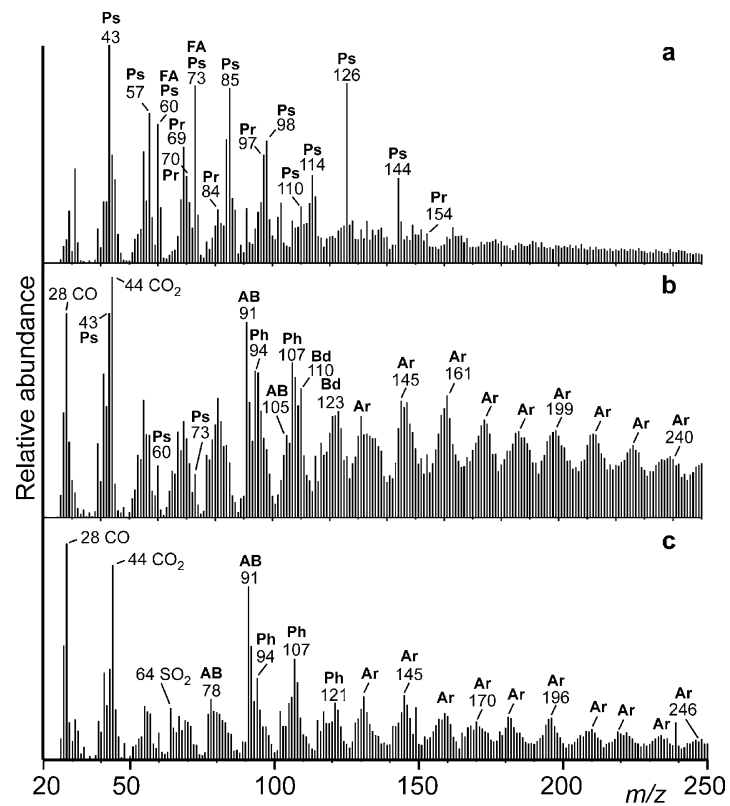

Fig. 1. EI DTMS spectra from cotyledons from peas (Pisum sativum variety 'Graauwe erwt'), (a) untreated peas (b) heated to $290{ }^{\circ} \mathrm{C}$ and (c) $400{ }^{\circ} \mathrm{C}$. Key: Ps polysaccharides, Pr proteins, FA fatty acids, $\mathrm{Ph}$ (alkyl)phenols, Bd (Benzenediols), AB (alkyl)benzenes, Ar condensed rings. For additional information see text.

changes are in accord with the coalification process (van Krevelen, 1993).

The mass underwent the expected decrease to c. $80 \%$ with the greatest loss occurring between c. 220 and $300{ }^{\circ} \mathrm{C}$. The initial decrease (i.e. up to $235^{\circ} \mathrm{C}$ ) could be related to the loss of water, with the sharp loss between c. 250 and $300{ }^{\circ} \mathrm{C}$ relating to the loss of carbon and hydrogen.

\subsection{DTMS}

Detailed molecular data from the low voltage EI DTMS analyses showed significant changes in the chemical composition (Fig. 1). Based on the differences in chemical composition three distinct groups of samples can be recognized.

The first group (Fig. 1a) is characterized by ions related to polysaccharide pyrolysis products including xylose $(m / z 85,114)$, hexoses $(m / z 126,144)$ and additional furan and pyran derivatives $(m / z 43,57,60,73$, 96, 98, 110, 112) (e.g. Moers et al., 1990; Pouwels and Boon, 1990). In addition, the untreated sample showed ions $m / z 69,70,81,97,131,138$ and 154 indicative of proteins (Boon en Haverkamp, 1979; Moers et al., 1990), their relative contribution being only minor. The presence of fats in the cotyledons was revealed by fatty acid ions $m / z 256$ and 282 and ions related to diacylglycerols ( $m / z 618,620$; not shown) and triacylglycerols
( $m / z 858,882,884,886$; not shown). The presence of fatty acids indicates that these will also have contributed to ions $m / z 60$ and 73. Samples heated to 130, 160, 190, $220,235{ }^{\circ} \mathrm{C}$ all showed the distinct presence of the polysaccharide products although their abundances decreased with increasing temperature.

The second group is characterized by the presence of ions $m / z$ 94, 107, 108, 110, 122, 123 and a distinct feature in the higher mass area showing a profile with dominant ions being $m / z$ 145, 146, 161, 174, 186, 199, 212, 216, 240 (Fig. 1b). Ions 94, 107, 108 and 122 are related to phenols that are formed as secondary pyrolysis products upon charring of glucose-based polysaccharides (Pastorova et al., 1994). The same holds true for ion 110 and possibly ions 123, 124 that are most probably related to benzenediols. These compounds have been shown to be formed in cellulose chars (Pastorova et al., 1994). The higher mass profile shows great similarity with the DTMS results of archaeological and cellulose chars (Oudemans and Boon, 1991; Pastorova et al., 1993) but the exact structures for these masses is as yet unknown although aromatics with one or more condensed benzene rings are the most probable precursors (Pastorova et al., 1993). Additional characteristic ions include $m / z$ 91, 92, 105 and 120 relating to simple alkylbenzenes. Increased release of elimination products $\mathrm{CO}$ and $\mathrm{CO}_{2}$ is witnessed by $m / z 28$ and 44, respectively. Samples heated to $250,270,290$ and $310^{\circ} \mathrm{C}$ belong to this group although it should be noted that phenols and benzenediols decrease with increasing temperature whereas the simple aromatics increase relative to the other compounds. These data clearly indicate that during heating the polysaccharide-protein based organic matter increasingly undergoes aromatization reactions. Combined with the observations of the internal morphology, these chemical data show that the starting biomacromolecules undergo transformation reactions leading to new macromolecules rather than being only lost preferentially as is proposed for cellulose from ligno-cellulose.

Mass ions $m / z$ 28, 44, 64, 78, 91, 105, 107 and a suite of high masses with a distinct pattern characterize the third group (Fig. 1c). The apparent relative increase of released elimination products, $\mathrm{CO}(\mathrm{m} / \mathrm{z} 28), \mathrm{CO}_{2}(\mathrm{~m} / \mathrm{z}$ 44) and $\mathrm{SO}_{2}(m / z 64)$ actually reflects the reduced production of products, most probably related to increased cross-linking within the organic matter present in the cotyledons. The increased abundance of aromatic moieties is revealed by the presence of simple benzenes $(\mathrm{m} / \mathrm{z}$ $78,91,106)$, although some evidence of phenols still remains $(m / z 94,107,108,121,122)$. The suite of high masses is believed to be related to (poly)aromatic compounds. All samples heated to $340{ }^{\circ} \mathrm{C}$ and higher temperatures belong to this group, although it should be noted that the DTMS results from the samples heated to $440{ }^{\circ} \mathrm{C}$ and above mainly show elimination products. 


\subsection{Stable carbon isotope changes}

Organic entities such as propagules and wood are composed of a number of macromolecules. Wood, for example, is composed of polysaccharides and lignin, each having a distinct stable carbon isotopic composition (Benner et al., 1987). Thus the bulk isotopic value of wood reflects the relative abundances of all the macromolecular components. To further complicate the issue selective degradation over time by fungi and bacteria can alter the carbon isotope ratio of wood through the preferential loss of one macromolecule (usually cellulose) over another (usually lignin) which, in turn, affects the bulk isotopic signature (Jones et al., 1993; Schleser et al., 1999; van Bergen and Poole, 2002). During decay, recreated in water at $180{ }^{\circ} \mathrm{C}$ over periods of minutes to months, Schleser et al. (1999) noted that the carbon isotope signature underwent a discrimination against ${ }^{13} \mathrm{C}$ during an initial phase (to a maximum of $\approx 1$ $\%$ ) followed by a subsequent increase in ${ }^{13} \mathrm{C} /{ }^{12}$ ratio up to the initial value $(-25.5 \%$ ). Schleser et al. (1999) explained this as the presumed preferential decomposition of the cellulose relative to the lignin. Jones et al. (1993) and Jones and Chaloner (1991) found that with experimentally charred wood there was a slight shift in isotopic composition by an average amount of $+0.2 \%$ when wood was heated to $300{ }^{\circ} \mathrm{C}$. From 300 to $500{ }^{\circ} \mathrm{C}$ the shift changed to $-0.4 \%$ and $-0.8 \%$ at $600{ }^{\circ} \mathrm{C}$. Again, this fractionation was explained by the volatilization of the isotopically heavier cellulose-derived carbon leaving the charcoal enriched in isotopically lighter lignin-derived carbon (Jones et al., 1993).

In contrast, propagules, for example, peas that are often found in archaeological sites (Bakels, 1984), have relatively fewer macromolecules, with the cotyledons composed primarily of polysaccharide. The stable carbon isotope results of the GE pea samples heated at both 1 and 2 h (Fig. 2a) revealed large variations without any specific direction, which to some extent could be related to the heterogeneity within extant peas (Engel, personal communication). However, apart from one sample $\left(290{ }^{\circ} \mathrm{C}\right), \delta^{13} \mathrm{C}$ values of the organic matter in all heated mixed peas had become enriched in ${ }^{13} \mathrm{C}$ by up to $1.5 \%$. The measurements of the individual NHR peas also reveal large differences in isotope composition both between and within temperatures (Fig. 2b). However, as with the GE pea samples, there is an initial ${ }^{13} \mathrm{C}$ enrichment phase and a final ${ }^{13} \mathrm{C}$ depletion phase but the majority of the values are ${ }^{13} \mathrm{C}$-enriched relative to the untreated peas, which is in line with the preferential loss of ${ }^{12} \mathrm{C}$ enriched $\mathrm{CO}_{2}$ from organic matter upon heating (Whiticar, 1996). Combining the isotope data with the DTMS results reveals that the largest isotope changes occur at temperatures during which many new secondary products are formed, in particular phenols, benzenediols and simple aromatics. The relative ${ }^{13} \mathrm{C}$
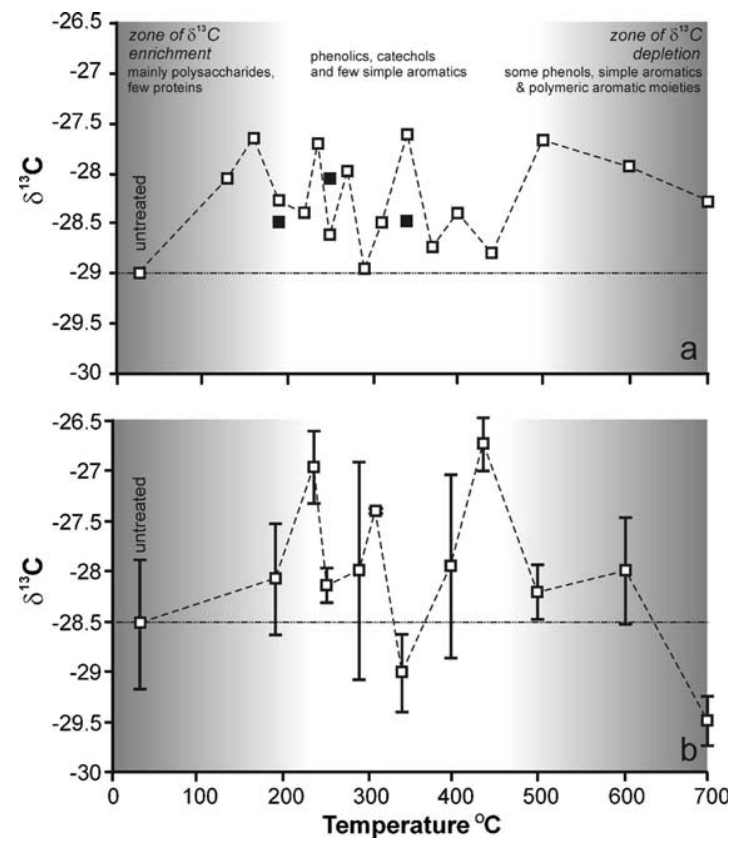

Fig. 2. (a) Graph showing the change in $\delta^{13} \mathrm{C}$ values each derived from a mix of two charred peas (Pisum sativum variety 'Graauwe erwt') after heating for either one (open squares) or 2 (closed squares) $\mathrm{h}$ in an oxygen depleted atmosphere up to $700{ }^{\circ} \mathrm{C}$ in relation to thermally unaltered (untreated) peas; (b) Graph showing the degree of variation in the $\delta^{13} \mathrm{C}$ value based on triplicate measurements of two individual peas of the same variety (Pisum sativum variety 'Noord-Hollandse rozijnerwt') around the mean value (open squares), with heating for $1 \mathrm{~h}$ in an oxygen depleted atmosphere up to $700{ }^{\circ} \mathrm{C}$ in relation to thermally unaltered (untreated) peas.

enrichment of the samples during the low temperature heating experiments may be related to the preferential loss of the fat component in the cotyledons as fatty acyl lipids are depleted in ${ }^{13} \mathrm{C}$ compared with the bulk of the organic matter (i.e. starch and proteins). To what extent the amount of cracking in the external surface of the peas during the heating experiment affects the isotope composition is as yet unknown, but one can anticipate that during enhanced cracking more $\mathrm{CO}_{2}$ would be released, leading to more ${ }^{13} \mathrm{C}$-enriched residues.

\subsection{Implications for palaeoclimate reconstructions}

In this study, the stable carbon isotope ratios of the predominantly polysaccharide based cotyledons of two varieties of pea have been found to vary between $-0.5 \%$ and $+2 \%$ with increased thermal activity when compared with the untreated value. A study undertaken by Marino and DeNiro (1987) on stable carbon isotope ratios of cellulose in archaeological food plants (Helianthus, Zea, Agave and Pachyrrhizus) stated that 
the ratios were conserved during food processing (including cooking) and thus reflect in vivo values even though the maximum differences between untreated and treated (involving carbonization) values were $+1 \%$, $+0.3 \%$, $-0.6 \%$, and $-1.2 \%$ respectively. These variations are of interest as they send a cautionary signal to isotopic palaeoclimatic studies which extend the use and value of existing plant organs found in archaeological and fossil sites for palaeo- and past climatic interpretations.

One example of such a study, that includes the use of stable carbon isotopes from fossil plants to infer climatic shifts during geological time, is that of Beerling and Jolley (1998), where a shift of $2 \%$ in fossil pollen at the Palaeocene-Eocene transition is taken as independent evidence for the transfer of isotopically light carbon from the ocean to the atmosphere. The shift noted by Beerling and Jolley (1998) is in the same range as the shift we observe here resulting from thermal alteration or the natural variation between pea varieties (Fig. 2a,b). To quantify the $2 \%$ shift, found both by Beerling and Jolly (1998) and our study in terms of $\delta^{13} C_{a}$, the following formula (Farquhar et al., 1989) was used:

$\Delta=\frac{\delta^{13} \mathrm{C}_{\mathrm{a}}-\delta^{13} \mathrm{C}_{\mathrm{pu}}}{1+\left(\delta^{13} \mathrm{C}_{\mathrm{pu}} / 1000\right)}$

where $\Delta$ represents the discrimination function, $\delta^{13} \mathrm{C}_{\mathrm{a}}$ represents the stable carbon isotope ratio of the atmosphere and $\delta^{13} \mathrm{C}_{\mathrm{pu}}$ represents the stable carbon isotope ratio of the untreated plant material. In this case the pea material $\left(\delta^{13} \mathrm{C}_{\mathrm{pu}}=-28.5 \%\right.$, Fig. $\left.2 \mathrm{~b}\right)$ was grown in the spring of 1999 at c. $52^{\circ} \mathrm{N}$ under a $\delta^{13} \mathrm{C}_{\mathrm{a}}$ of $-8.2 \%$ (see http://wwwsrv.cmdl.noaa.gov/ccgg/figures/figures.html). This gives a $\delta^{13} \mathrm{C}$ discrimination of $20.3 \%$. Using this value to determine $\delta^{13} \mathrm{C}_{\mathrm{a}}$ when $\delta^{13} \mathrm{C}$ of the thermally altered peas $\delta^{13} \mathrm{C}_{\mathrm{pa}}=-26.5 \%$ o (maximum value from the experimentally charred pea material; Fig. 2b) gives stable carbon isotope ratios of the atmosphere $\approx-6.1 \%$ o i.e. a $2.1 \%$ shift from the actual value of $\delta^{13} \mathrm{C}_{\mathrm{a}}$. This shift approaches that of $2.3 \%$ noted across the Palaeocene-Eocene boundary (Beerling, 2000) indicating that the combined use of charred/charcoalified and uncharred organic matter (Hesselbo et al., 2000) may induce spurious interpretations.

\section{Summary}

Understanding the changes in isotope composition of thermally altered organic matter is crucial for accurate evaluation of the isotope record from fossil plant remains. The type of organ, the species (Sternberg and DeNiro, 1983), their bio/geomolecular composition and any alteration before, during or after preservation all have to be taken into consideration when working with archaeological and fossil material including charcoal and coals (which themselves can not be compared directly with uncharred or uncharcoalified material).

Unfortunately, however, one variable, namely the intrinsic isotopic variability which occurs within plants, will always remain unknown for fossil or archaeological material. The degree and directionality of stable carbon isotopic changes can then be assessed and corrected for, if necessary, prior to meaningful palaeoclimatic interpretations. Additional analyses of other propagules (i.e. different varieties of peas, wheat and flax) in conjunction with studies on vitrinite reflectance versus thermal intensity (Braadbaart et al., unpublished results) are currently being undertaken to determine the extent to which these observations can be generalized.

\section{Acknowledgements}

We thank Drs. H. Veld, P. David and Miss K. Reimer for help with the element analyses, Mr. J. van der Horst and Mr. G. Nobbe for their assistance with the DTMSand IRMS analyses respectively, and Dr. M. Engel whose comments have improved this manuscript. This work was funded in part by NWO grant number ALW/ 809.32.004 which is greatly appreciated.

\section{References}

Arens, N.C., Jahren, A.H., Amundson, R., 2000. Can C $_{3}$ plants faithfully record the carbon isotopic composition of atmospheric carbon dioxide? Palaeobiology 26, 137-164.

Bakels, C.C., 1984. Carbonized seeds from northern France. Analecta Praehistorica Leidensia 17, 1-125.

Bailey, J.G., Tate, A., Diessel, C.F.K., Wall, T.F., 1990. A char morphology system with applications to coal combustion. Fuel 69, 225-239.

Beerling, D.J., 2000. Increased terrestrial carbon storage across the Palaeocene-Eocene boundary. Palaeogeography, Palaeoclimatology, Palaeoecology 161, 395-405.

Beerling, D.J., Jolley, D.W., 1998. Fossil plants record as atmospheric ${ }^{12} \mathrm{CO}_{2}$ and temperature spike across the Palaeocene-Eocene transition in NW Europe. Journal of the Geological Society $155,591-594$.

Benner, R., Fogel, M.L., Sprague, E.K., Hodson, R.E., 1987. Depletion of ${ }^{13} \mathrm{C}$ in lignin and its implication for stable carbon isotope studies. Nature 329, 708-710.

Boon, J.J., Haverkamp, J., 1979. Pyrolysis mass spectrometry of a benthic marine ecosystem. Netherlands Journal of Sea Research 13, 457-478.

Collinson, M.E., 1983. The Palaeontological Association Field Guide to Fossils. Number 1. Fossil Plants of the London Clay. Oxford University Press.

Daveby, Y.D., Abrahamsson, M., Ãman, P., 1993. Changes in chemical composition during development of three different types of peas. Journal of Science Food and Agriculture 63, $21-28$. 
DeNiro, M.J., Hastorf, C.A., 1985. Alteration of ${ }^{15} \mathrm{~N} /{ }^{14} \mathrm{~N}$ and ${ }^{13} \mathrm{C} /{ }^{12} \mathrm{C}$ ratios of plant matter during the initial stages of diagenesis: studies utilizing archaeological specimens from Peru. Geochimica et Cosmochimica Acta 49, 97-115.

Farquhar, G.D., Ehleringer, J.R., Hubick, K.T., 1989. Carbon isotope discrimination and photosynthesis. Annual Reviews of Plant Physiology and Plant Molecular Biology 40, 503547.

Figueiral, I., Willcox, G., 1999. Archaeobotany: collecting and analytical techniques for sub-fossils. In: Jones, T.P., Rowe, N.P. (Eds.), Fossil Plants and Spores modern techniques. The Geological Society, London, pp. 290-294.

Gröcke, D.R., 1998. Carbon-isotope analyses of fossil plants as a chemostratigraphic and palaeoenvironmental tool. Lethaia 31, 1-13.

Gröcke, D.R., Hesselbo, S.P., Jenkyns, H.C., 1999. Carbonisotope composition of Lower Cretaceous fossil wood: ocean-atmosphere chemistry and relation to sea-level change. Geology 27, 155-158.

Hesselbo, S.P., Gröcke, D.R., Jenkyns, H.C., Bjerrum, C.J., Farrimond, P., Morgans Bell, H.S., Green, O.R., 2000. Massive dissociation of gas hydrate during a Jurassic oceanic anoxic event. Nature 406, 392-395.

Jones, T.P., Chaloner, W.G., 1991. Fossil charcoal, its recognition and palaeoatmospheric significance. Palaeogeography, Palaeoecology, Palaeoclimatology (Global Planetary Change Section) 97, 39-50.

Jones, T.P., Scott, A.C., Mattey, D.P., 1993. Investigations of "fusian transition fossils" from the Lower Carboniferous: comparisons with modern partially charred wood. International Journal of Coal Geology 22, 37-59.

Kürschner, W.M., van der Burgh, J., Visscher, H., Dilcher, D.L., 1996. Fossil oak leaves as biosensors of Late Neogene to early Pleistocene paleoatmospheric $\mathrm{CO}_{2}$ concentrations. Marine Micropaleontology 27, 299-312.

Lücke, A., Helle, G., Schleser, G.H., Figueiral, I., Mosbrugger, V., Jones, T.P., Rowe, N.P., 1999. Environmental history of the German Lower Rhine Embayment during the Middle Miocene as reflected by carbon isotopes of brown coal. Palaeogeography, Palaeoclimatology, Palaeoecology 154, 339-352.

Marino, B.D., DeNiro, M.J., 1987. Isotopic analysis of archaeobotanicals to reconstruct past climates: Effects of activities associated with food preparation on carbon, hydrogen and oxygen isotope ratios of plant cellulose. Journal of Archaeological Science 14, 537-548.

Moers, M.E.C., Baas, M., Boon, J.J., de Leeuw, J.W., 1990. Molecular characterization of total organic matter and carbohydrates in peat samples from a cypress swamp by pyrolysis-mass spectrometry and wet-chemical methods. Biogeochemistry 11, 251-277.

Oudemans, T.F.M., Boon, J.J., 1991. Molecular archaeology: analysis of charred (food) remains from prehistoric pottery by pyrolysis-gas chromatography/mass spectrometry. Journal of Analytical and Applied Pyrolysis 20, 197-227.

Pastorova, I., Oudemans, T.F.M., Boon, J.J., 1993. Experimental polysaccharide chars and their fingerprints in charred archaeological food residues. Journal of Analytical and Applied Pyrolysis 25, 63-75.

Pastorova, I., Botto, R.E., Arisz, P.W., Boon, J.J., 1994. Cellulose char structure - a combined analytical Py-GC-MS, FTIR, and NMR-study. Carbohydrate Research 262, $27-47$.

Peters-Kotting, W., Stauss, H., Kerp, H., 2001. The carbon isotopic composition of terrestrial organic matter from the Late Paleozoic. Terra Nostra 4, 52-56.

Poole, I., 2000. Fossil angiosperm wood anatomy: its role in the reconstruction of biodiversity and palaeoenvironment. Botanical Journal of the Linnean Society 134, 361-381.

Pouwels, A.D., Boon, J.J., 1990. Analysis of beech wood samples, its milled wood lignin and polysaccharide fractions by curie-point and platinum filament pyrolysis mass-spectrometry. Journal of Analytical and Applied Pyrolysis 17, 97-126.

Reid, E.M., Chandler, M.E.J., 1933. The Flora of the London Clay. British Museum (Natural History), London.

Schleser, G.H., Frielingsdorf, J., Blair, A., 1999. Carbon isotope behaviour in wood and cellulose during artificial aging. Chemical Geology 158, 121-130.

Schmidt, M.W.I., Noack, A.G., 2000. Black carbon in soils and sediments: analysis, distribution, implications, and current challenges. Global Biogeochemical Cycles 14, 777-793.

Schmidt, M.W.I., Skjemstad, J.O., Gehrt, E., Kögel-Knabner, I., 1999. Charred organic carbon in German chernozemic soils. European Journal of Soil Science 50, 351-365.

Sricharoenchaikul, V., Hicks, A.L., Frederick, W.J., 2001. Carbon and char residue yields from rapid pyrolysis of kraft black liquor. Bioresource Technology 77, 131-138.

Sternberg, L., DeNiro, M.J., 1983. Isotopic composition of cellulose from $\mathrm{C}_{3}, \mathrm{C}_{4}$ and CAM plants growing in the vicinity of one another. Science 220, 947-949.

van Bergen, P.F., Poole, I., 2002. Stable carbon isotopes in wood: a clue to palaeoclimate? Palaeogeography, Palaeoclimatology, Palaeoecology 182, 31-45.

van Krevelen, D.W., 1993. Coal. Elsevier, Amsterdam.

Wheeler, E.A., Baas, P., 1993. The potentials and limitations of dicotyledonous wood anatomy for climatic reconstructions. Palaeobiology 19, 487-498.

Wiemann, M.C., Manchester, S.R., Wheeler, E.A., 1999. Paleotemperature estimation from dicotyledonous wood anatomical characters. Palaios 14, 459-474.

Wiemann, M.C., Wheeler, E.A., Manchester, S.R., Portier, K.M., 1998. Dicotyledonous wood anatomical characters as predictors of climate. Palaeogeography, Palaeoclimatology, Palaeoecology 139, 83-100.

Whiticar, M.J., 1996. Stable isotope geochemistry of coal, humic kerogens and related natura; gases. International Journal of Coal Geology 32, 191-215. 